\title{
New evidence for the involvement of Paracartia grani (Copepoda, Calanoida) in the life cycle of Marteilia refringens (Paramyxea)
}

\author{
S. Boyer ${ }^{a, *}$, B. Chollet $^{b}$, D. Bonnet ${ }^{a}$, I. Arzul ${ }^{b}$
}

\author{
a Laboratoire EcoSym, UMR5119, Université Montpellier 2, CC 093, Place Eugène Bataillon, 34095 Montpellier \\ Cedex 05, France \\ b Laboratoire de Génétique et Pathologie des Mollusques Marins, IFREMER, SG2M-LGPMM, Avenue Mus de \\ Loup, 17390 La Tremblade, France
}

\author{
*: Corresponding author : Séverine Boyer, tel.: +33467144047 ; fax: +33467143719 ; \\ email address : Severine.Boyer@univ-montp2.fr
}

\begin{abstract}
:
The dynamics of the protozoan parasite Marteilia refringens was studied in Thau lagoon, an important French shellfish site, for 1 year in three potential hosts: the Mediterranean mussel Mytilus galloprovincialis (Mytiliidae), the grooved carpet shell Ruditapes decussatus (Veneriidae) and the copepod Paracartia grani (Acartiidae). Parasite DNA was detected by PCR in R. decussatus. In situ hybridisation showed necrotic cells of $M$. refringens in the digestive epithelia of some $R$. decussatus suggesting the non-involvement of this species in the parasite life cycle. In contrast, the detection of $M$. refringens in mussels using PCR appeared bimodal with two peaks in spring and autumn. Histological observations of PCR-positive mussels revealed the presence of different parasite stages including mature sporangia in spring and autumn. These results suggest that the parasite has two cycles per year in the Thau lagoon and that mussels release parasites into the water column during these two periods. Moreover, PCR detection of the parasite in the copepodid stages of P. grani between June and November supports the hypothesis of the transmission of the parasite from mussels to copepods and conversely. In situ hybridisation performed on copepodites showed labeling in some sections. Unusual $M$. refringens cells were observed in the digestive tract and the gonad from the third copepodid stage, suggesting that the parasite could infect a copepod by ingestion and be released through the gonad. This hypothesis is supported by the PCR detection of parasite DNA in copepod eggs from PCR-positive females, which suggests that eggs could contribute to the parasite spreading in the water and could allow overwintering of $M$. refringens. Finally, in order to understand the interactions between mussels and copepods, mussel retention efficiency (number of copepods retained by a mussel) was measured for all $P$. grani developmental stages. Results showed that all copepod stages could contribute to the transmission of the parasite, especially eggs and nauplii which were retained by up to $90 \%$.
\end{abstract}




\section{Graphical abstract}

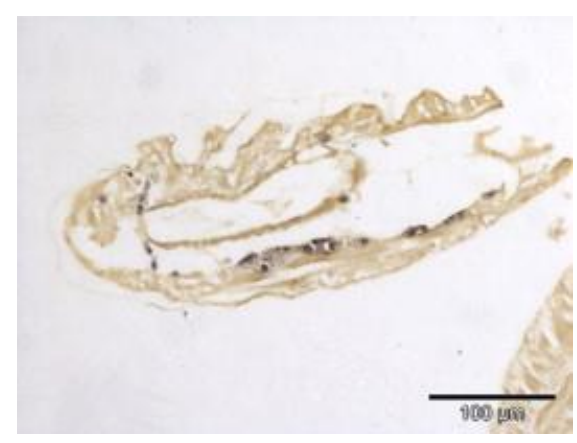

\section{Highlights}

Marteilia refringens was studied in bivalves: Mytilus galloprovincialis, Ruditapes decussatus and copepods Paracartia grani. A non-involvement of clams in the parasite life cycle is suggested. Mature sporangia were observed in mussels in spring and autumn. Unusual parasite cells were observed in the digestive tract and gonad in young and adult copepodite stages of the copepod. Positive PCR detections were observed in copepod eggs and all copepod developmental stages were retained by mussels.

Keywords : Marteiliosis ; Marteilia refringens ; Parasite life cycle ; Mytilus galloprovincialis ; Ruditapes decussatus ; Paracartia grani ; PCR ; In situ hybridisation 


\section{Introduction}

Marteilia refringens is a protozoan parasite responsible for marteiliosis, a major disease of economically important bivalves in Europe. This infection requires mandatory notification to the World Organization for Animal Health and the European Union. Marteilia refringens was first described in 1968 in the European flat oyster, Ostrea edulis, in Aber Wrach, Brittany (France) (Comps, 1970), and has caused mass mortalities in this species (Alderman, 1979; Grizel, 1985, Etudes des récentes épizooties de l'huître plate (Ostrea edulis) et leur impact sur l'ostréiculture bretonne. PhD Thesis, University of Montpellier 2, France). Since its discovery in 0 . edulis, several other commercial bivalve species have been found to be infected with the parasite including mussels Mytilus edulis (Comps et al., 1975), Mytilus galloprovincialis (Comps and Joly, 1980) (Mytiliidae), clams, Ruditapes decussatus (Villalba, A., López, M.C., Carballal, M.J., 1993a. Parasites and pathologic conditions of three clam species, Ruditapes decussatus, Venerupis pullastra, and Venerupis rhomboides, in the Galician Rias, Actas IV Congreso Nac. Acuicult. Centro de Investigaciones Marinas, Pontevedra (Spain). 551-556.), Chamelea gallina (Veneriidae) and razor shells, Solen marginatus (Soleniidae) (López-Flores et al., 2008a, b).

Infections with $M$. refringens have been recorded in many mollusc species in an area extending from the North Sea (Sweden) (OIE, 2010, report reference 8982, 25/01/2012, Sweden, http://www.oie.int/wahis 2/public\%5C..\%5Ctemp\%5Creports/en fup 0000008982201002251 83643.pdf) and Atlantic coasts from the south of England to Morocco, including Brittany (France), Galicia and Andalusia (Spain) (Le Roux et al., 2001; López-Flores et al., 2004; Novoa et al., 2005). The parasite has also been detected in the Mediterranean basin at Catalunya (Spain) (Carrasco et al., 2007a, b), Tunisia (Elgharsalli et al., 2013), Croatia (Zrnčić et al., 2001), Italy (the Adriatic and Campanian coast) (Tieri et al., 2006; Carella et al., 2010), Albania (Pëllumb et al., 2006), Greece (Virvilis et al., 2003; Karagiannis and Angelidis, 2007) and Turkey (I. Arzul, Personal Comunication).

Previous experimental transmission studies consisting of either inoculating $M$. refringens cells directly into molluscs or associating infected with non-infected molluscs have failed, suggesting that an intermediate host might be required in the life cycle (Berthe et al., 1998). More recently, this assumption was supported by detection of the parasite in the ovary of the copepod Paracartia grani in the 'Claire' ponds of Marennes-Oléron (France) (Audemard et al., 2002). In this confined shallow system, the infection of flat oysters, Ostrea edulis, with $M$. refringens is observed from June to August, when temperatures are greater than $17^{\circ} \mathrm{C}$ and the maximum abundance of $P$. grani (Audemard et al., 2001) is recorded. When considering the currently available information, the correlation between the distributions of $M$. refringens and $P$. grani in Europe strengthens the hypothesis of the involvement of the copepod in the parasite life cycle (Boyer, 2012, Ecologie du Copépode Calanoïde Paracartia grani. Implication dans le cycle de vie du parasite Marteilia refringens dans la lagune de Thau. PhD Thesis, University of Montpellier 2. France). However, subsequent studies have shown that other zooplankton species might also play a role in the transmission of $M$. refringens. Indeed, the parasite has been detected by PCR in several copepod species including Euterpina acutifrons, Oithona sp., Acartia clausi, Acartia discaudata, Acartia italica, and the brachyuran zoea of decapods (Carrasco et al., $2007 a, b)$. Consistent PCR detections of the parasite were also reported in the cnidarian Cereus pendunculatus (Audemard et al., 2002). 
Thau lagoon contributes approximately $70 \%$ of the French Mediterranean production of shellfish with 8,200 and 3,500 tons of oysters (Crassostrea gigas) and mussels (My. galloprovincialis) produced per year, respectively (Gervasoni, E., Perignon, A., Sourisseau, E., Rey-Valette, H., Lagarde, F., Pérez, J., Yimam, E., Feldman, N., 2011. Monographie de la conchyliculture en Méditerranée-Mars 2011. http://archimer.ifremer.fr/doc/00124/23509/21342.pdf). Marteiliosis was detected at this site in the late 1970s in flat oysters, Ostrea edulis (Comps, 1979, Etude du cycle de Marteilia refringens dans l'étang de Thau. CIEM Conseil International pour l'Exploration de la Mer. http://archimer.ifremer.fr/doc/00000/6078/3.), and then in mussels, My. galloprovincialis (Reseau de Pathologies des Mollusques (REPAMO), 2007, http://archimer.ifremer.fr/doc/00086/19708/17349.pdf). Nowadays, in the lagoon $O$. edulis has almost completely disappeared and detection frequencies of $M$. refringens in $M y$. galloprovincialis have fluctuated between 21.5\% in 1985 (Pichot, Y., 2002. Bilan de l'état zoosanitaire des mollusques en méditerranée française 1988-2001, http://archimer.ifremer.fr/doc/00145/25579/_) and 2.86\% in 2006 while no associated mortality has been reported (REPAMO, 2007, http://archimer.ifremer.fr/doc/00086/19708/17349.pdf). It has been shown that uninfected bivalves which moved into the lagoon quickly developed the disease (Comps, 1979, cited earlier; Zrnčić et al., 2001). Furthermore, some zooplanktonic species reported as potential intermediate hosts in Marteilia life cycles are recorded in Thau lagoon, especially the copepod P. grani (Boyer et al., 2012).

In Thau lagoon, as in many semi-enclosed areas such as estuaries, harbours, bays and lagoons, copepods of the Acartiidae dominate the mesozooplankton community (Mathias and Euzet, 1962; Lam Hoai, 1985). Paracartia grani was first recorded in Thau lagoon in 1998 (Boyer et al., 2012). Nowadays, it occurs in the water column from the end of April to January and in the sediment as diapause eggs during the rest of the year (Boyer and Bonnet, 2013; Boyer et al., 2013). Despite several studies performed on the involvement of zooplankton in the life cycle of $M$. refringens (Audemard et al, 2002; Carrasco et al., 2007a, b), some questions remain unresolved. Indeed, as the parasite has previously been observed in the gonads of adults females of $P$. grani, we speculate whether $P$. grani females can transmit marteiliosis to their offspring. Moreover, until now, the presence of $M$. refringens has only been confirmed in adult or pre-adult $P$. grani which are large organisms $(>700 \mu \mathrm{m})$.

In the present study, we monitored, using PCR, the presence of the parasite for 1 year in Thau lagoon in all $P$. grani copepodite stages and in two bivalve species: the Mediterranean mussel, My. galloprovincialis, and the grooved carpet clam, $R$. decussatus. The aim of the study was to describe, using histology and in situ hybridization (ISH), the contribution of these three potential hosts to the life cycle of $M$. refringens. Furthermore, considering that the parasite has previously been detected in the ovarian tissue of $P$. grani, we explored whether eggs produced by PCRpositive females could be infected with $M$. refringens. Lastly, the retention efficiency of mussels for all $P$. grani developmental stages (from eggs to adults) was measured experimentally to better understand interactions between copepods and bivalves in the $M$. refringens life cycle. Results obtained from both field and experimental works provide new evidence of the contribution of $P$. grani to the life cycle of $M$. refringens . 


\section{Materials and methods}

\subsection{Zooplankton and bivalve sampling}

In 2010, mesozooplankton was collected twice each month close to the Sète channel in Thau lagoon $\left(43^{\circ} 25 \mathrm{~N} ; 03^{\circ} 40 \mathrm{E}\right)$ (Southern France) (Fig. 1). A WP2 plankton net with a $200 \mu \mathrm{m}$ mesh size was used to collect mesozooplankton in three horizontal hauls in the inner surface water (maximum $1 \mathrm{~m}$ depth). The first sample was fixed with buffered formaldehyde at a final concentration of $4 \%$ and used to determine the contribution of $P$. grani to total mesozooplankton abundance. The second sample was placed in insulated containers and brought back to the laboratory within $1 \mathrm{~h}$ of collection to conduct experiments of egg production. The third sample was divided into two subsamples; one was fixed in 95\% ethanol and the second in Davidson's fixative for $24 \mathrm{~h}$ and then in $70 \%$ ethanol for PCR and histological analyses respectively. Based on their abundance in the water column, between 20 and 50 individuals per developmental stage of $P$. grani were collected in $95 \%$ ethanol to perform PCR detections. Stages $\mathrm{Cl}$ and $\mathrm{Cll}$ of species of Acartiidae were not differentiated because the morphology of these two stages is very similar in P. grani and Acartia clausi, both recorded at the monitoring site. Samples collected in June, October, November and December were pooled for each month because $P$. grani abundance was low at these dates.

Thirty individuals of My. galloprovincialis and $R$. decussatus were collected monthly by diving at the study site over 1 year (Fig. 1). A part of the digestive gland of each organism was fixed in $95 \%$ ethanol for molecular analyses and a portion of the animal was fixed in Davidson's fixative for $24 \mathrm{~h}$ and then in $70 \%$ ethanol for histological or ISH analyses.

\subsection{DNA extraction and PCR detection of $M$. refringens in copepods and bivalves}

DNA was extracted from pools of $P$. grani copepodites and from the digestive gland of bivalves. Total DNA was extracted with DNAzol $®$ reagent, according to the manufacturer's protocol (Invitrogen ${ }^{\mathrm{TM}}$, U.S.A) and eluted in $20 \mu \mathrm{l}$ of $8 \mathrm{mM} \mathrm{NaOH}$.

All samples were first tested by PCR using eukaryotic "universal" primers to check the absence of PCR inhibitors according to Le Roux et al. (1999). Two PCR assays were then used to specifically detect $M$. refringens: the first assay amplified 412 bp from the internal transcribed spacer-1 (ITS-1) of the parasite genome (Le Roux et al., 2001). The second assay consisted of a nested PCR targeting the rDNA intergenic spacer sequence (IGS) according to López-Flores et al. (2004) and has previously been shown to be more sensitive (Carrasco et al., 2007a).

DNA suspensions from mussels were tested using an ITS-1 assay. Considering the faint amplification observed when testing $R$. decussatus DNA suspensions with the ITS- 1 assay, the presence of $M$. refringens DNA in $R$. decussatus was checked using the nested PCR assay. Finally, both PCR assays were used to test $P$. grani DNA samples. Negative PCR controls consisting of DNA-free water were included in order to check potential contamination. Positive PCR controls corresponding to DNA extracted from copepods and mussels previously found infected with $M$. refringens were included in each PCR test.

In order to confirm the specificity of PCR products obtained by nested PCR for $R$. decussatus and $P$. grani copepodites, some of these PCR products were selected for direct sequencing. 
Sequences obtained were compared with those included in GenBank using the BLAST algorithm (Altschul et al., 1990).

\subsection{Egg production (EP) experiments and detection of $M$. refringens in $P$. grani eggs}

Paracartia grani egg production (EP) experiments were conducted to determine whether $M$. refringens could be transmitted from adult females to their eggs. In the laboratory, five EP experiments were performed between September and November. Indeed, a previous study has shown that during this period, $P$. grani females were PCR-positive for $M$. refringens in the lagoon (Boyer, 2012, PhD thesis, cited earlier). The physiological state of the female (ovigerous versus non-ovigerous) was determined under a binocular microscope. For each EP experiment, 20 to 100 females of $P$. grani were selected and incubated together for $24 \mathrm{~h}$ in a $1 \mathrm{~L}$ beaker filled with filtered $(0.45 \mu \mathrm{m})$ lagoon water $(\mathrm{FLW})$. The beaker contained a Plexiglas insert with a $200 \mu \mathrm{m}$ mesh false bottom to separate eggs from females and to avoid cannibalism. The next day, females and eggs were fixed in $95 \%$ ethanol for further analyses. Eggs were sieved on a $40 \mu \mathrm{m}$ mesh sized sieve and rinsed quickly in FLW prior to being fixed in $95 \%$ ethanol. Pools of females were analyzed together for each experiment by PCR targeting the ITS-1 and inter generic spacer IGS.

Eggs obtained from $P$. grani females found positive by ITS-1 and/or IGS PCR were selected for further analyses. PCR assays were performed directly on pools of 30 eggs without previous DNA extraction, according to a protocol adapted from Lindeque et al. (2013). Following an incubation in $10 \mu \mathrm{l}$ of DNA-free water for 4 to $6 \mathrm{~h}$ at room temperature, $20 \mu \mathrm{l}$ of 5X GoTAQ® DNA polymerase buffer (Promega, U.S.A.) were added to each pool of eggs. Samples were then sonicated to crush the chorion and incubated overnight at $4^{\circ} \mathrm{C}$. The next day, each sample was divided into two equivalent parts to perform ITS-1 and IGS PCR. The remaining PCR components were then added: $27.75 \mu \mathrm{l}$ of DNA-free water, $5 \mu \mathrm{l}$ of $5 X$ GoTAQ® DNA polymerase buffer (Promega, U.S.A), $1 \mu \mathrm{l}$ of $10 \mathrm{mM}$ dNTPs (Promega, U.S.A), $0.5 \mu \mathrm{l}$ of $50 \mu \mathrm{M}$ of each primer and $1.25 \mathrm{U}$ GoTAQ® DNA polymerase (Promega, U.S.A). Amplifications were then carried out according to Le Roux et al. (2001) and López-Flores et al. (2004). A preliminary assay using eukaryotic "universal" primers was also run to check the absence of PCR inhibitors according to Le Roux et al. (1999). PCR products obtained by nested PCR were selected for direct sequencing.

\subsection{Histological description of $M$. refringens in My. galloprovincialis}

ITS-1 PCR-positive mussels were selected for histological examination. Samples were dehydrated and embedded in paraffin wax. Paraffin blocks were cut at $3 \mu \mathrm{m}$ and stained with $\mathrm{H}$ $\& \mathrm{E}$. The presence of young and mature stages of $M$. refringens were noticed and located in the different tissues. All of the digestive tissues present on the sections were screened to determine the number of mussels with mature stages (sporangia).

\subsection{In situ hybridization (ISH) analyses of $P$. grani and $R$. decussatus}

Paracartia grani stages and $R$. decussatus samples found to be PCR-positive were tested by ISH with a probe targeting $18 \mathrm{~S}$ rDNA (probe Smart2) according to a protocol adapted from Le Roux et al. (1999). Five $\mu \mathrm{m}$ thick tissue sections on silane-prep ${ }^{\mathrm{TM}}$ slides (Sigma, France) were dewaxed, rehydrated and treated with proteinase $\mathrm{K}\left(100 \mu \mathrm{g} \mathrm{mL} \mathrm{m}^{-1}\right.$ in TE buffer [Tris $50 \mathrm{mM}$, 
EDTA $10 \mathrm{mM}, \mathrm{NaCl} 10 \mathrm{mM}]$ ) at $37^{\circ} \mathrm{C}$ for $10 \mathrm{~min}$. Slides were dehydrated by immersion in an ethanol series and air-dried. Sections were then incubated with $100 \mu \mathrm{L}$ of hybridization buffer (50\% formamide, $1 X$ dextran sulfate, $4 \times$ SSC [0.06 M Na 3 Citrate, $0.6 \mathrm{M} \mathrm{NaCl}, \mathrm{pH}$ 7], $250 \mu \mathrm{gL}^{-}$ yeast tRNA and $10 \%$ Denhardt's solution) containing $10 \mathrm{ng} \mathrm{\mu L}^{-1}$ of the digoxigenin-labelled probe. Targeted DNA and digoxigenin-labelled probes were denatured at $95^{\circ} \mathrm{C}$ for 5 min and the hybridization was carried out overnight at $42^{\circ} \mathrm{C}$. Sections were washed in $2 \times$ saline-sodium citrate (SSC) at room temperature $(2 \times 5 \mathrm{~min})$, in $0.4 \times \mathrm{SSC}$ at $42{ }^{\circ} \mathrm{C}(10 \mathrm{~min})$ and in solution I (100 mM maleic acid, $0.15 \mathrm{M} \mathrm{NaCl}, \mathrm{pH} 7.5)$ for $5 \mathrm{~min}$. Tissues were then blocked for $30 \mathrm{~min}$ at room temperature with blocking reagent (Roche, Germany) $(1 \% \mathrm{w} / \mathrm{v})$ in solution I. Specifically bound probe was detected using an alkaline phosphatase-conjugated mouse IgG antibody against digoxigenin diluted at $1.5 \mathrm{U} \mathrm{mL}^{-1}$ in solution I blocking reagent ( $1 \mathrm{~h}$, room temperature). Excess antibody was removed by two washes in solution I (1 $\mathrm{min}$ ) and one wash in solution II (0.1 M Tris $\mathrm{pH} 8,0.1 \mathrm{M} \mathrm{NaCl}, 0.05 \mathrm{M} \mathrm{MgCl}_{2}, \mathrm{pH}$ 9.5). Slides were incubated in NBT/BCIP, a chromogenic substrate for alkaline phosphatase, diluted in solution II $\left(20 \mu \mathrm{L} \mathrm{mL}^{-1}\right)$ in the dark until the parasitic cells were completely stained black-purple. The reaction was stopped with solution III (100 mM Tris, $1 \mathrm{mM}$ EDTA, $\mathrm{pH}$ 8). Slides were counterstained for 1 min with Bismarck brown yellow (5 g L $\mathrm{g}^{-1}$ in ethanol 30\%), dehydrated with ethanol and mounted in Eukitt resin. Negative controls included samples without digoxigenin-labeled probe in hybridization mixture. Positive control consisted in sections from flat oysters $O$. edulis infected with $M$. refringens originating from Leucate (France).

\subsection{Measurement of the retention efficiency of mussels on the developmental stages of P. grani}

Developmental stages of $P$. grani (from eggs to adults) obtained from experimental cultures were used to estimate the retention efficiency of $M y$. edulis on $P$. grani. Eggs from laboratory cultures were placed in $5 \mathrm{~L}$ of $0.2 \mu \mathrm{m}$ filtered sea water (FSW) at $19 \pm 2^{\circ} \mathrm{C}$, salinity $35 \pm 1$ and with a $12 \mathrm{~h}$ dark:12 $\mathrm{h}$ light photoperiod. Copepods were fed daily to saturation (based on the water color) with Rhodomonas baltica. To determine the size spectra of stages of $P$. grani retained by mussels, seven groups of $P$. grani were constituted depending on the length of the organisms: eggs, third and fourth naupliar stages (NIII-NIV), fifth and sixth naupliar stages (NV$\mathrm{NVI}$ ), first and second copepodid stages (Cl-CII), third and fourth copepodid stages (CIII-CIV), fifth copepodid stage (CV) and sixth copepodid stage (adults; CVI). The quantity of nauplii used in each experiment was close to the maximum occurrence of acartiid nauplii observed in Thau lagoon. The number of copepodites for each experiment was 10 times higher than their maximum in situ abundance recorded in Thau lagoon (Boyer, 2012, PhD thesis, cited earlier). Each group, consisting of either 100 eggs, 18 nauplii or 22 copepodites, was placed for $1 \mathrm{~h}$ in 1 $\mathrm{L}$ of $0.2 \mu \mathrm{m}$ FSW together with one mussel, My. edulis. The mussel was suspended on a net in the crystallizer to allow opening and a stream of water was simulated with a magnetic stirrer. Beforehand, mussels were taken out of the water for $1 \mathrm{~h}$ to enhance their filtration rate. The experiments were replicated (depending on the quantity of $P$. grani stages available): four times for eggs, NIII-NIV and NV-NVI groups, and nine times for all copepodid stages. At the end of each experiment, mussels were removed and the number of remaining $P$. grani counted. The retention efficiency $(\mathrm{RE})$ was determined from the equation below:

$$
\mathrm{RE}=(\mathrm{Ti}-\mathrm{Tf} / \mathrm{Ti}) \times 100
$$

Where $\mathrm{Ti}$ and $\mathrm{Tf}$ are the initial and final numbers of $P$. grani respectively. 
A non-parametric Kruskal-Wallis ANOVA was first applied to test differences in $M$. edulis retention efficiency according to the stage of $P$. grani studied. Then multiple comparison tests with post-hoc analyses were performed using the "pgirmess" package (Giraudoux, P., 2012, Package "pgirmess" in Data analysis in ecology. R package, version 1.5.4. Available at: http://cran.r-project.org/web/packages/pgirmess) in R (R Core Development Team, 2009, R: a language and environment for statistical computing version 2.12.1. Available at: http://www.rproject.org.) allowing testing for differences between groups.

\section{Results}

\subsection{Detection of $M$. refringens in $P$. grani copepodites}

Paracartia grani was present in the water column from the end of April (abundance $<1$ individual $\mathrm{m}^{-3}$ ) to the end of January with a maximal contribution to the total mesozooplankton abundance in September (Fig. 2A). During its occurrence in the lagoon, at least one sample collected each month was PCR-positive for $M$. refringens, except in December. CV and adult females were the main stages which were PCR-positive (Fig. 2B). Nevertheless, other copepodid stages including CI, CII, CIII, CIV females and CV males were also found positive by nested PCR in August and September when P. grani contribution to total mesozooplankton abundance was maximal (Fig. 2B).

\subsection{Location of $M$. refringens in $P$. grani}

Positive labeling was observed in CIII, CV and adults females of $P$. grani by ISH (Fig. 2B). Marteilia refringens was observed in Clll for the first time, in the alimentary canal (Fig. 3A), the digestive epithelium (Fig. 3B), and the germinal site (probably ovarian tissues) (Fig. 3C). Cells showing different sizes (from 3 to $10 \mu \mathrm{m}$ ) presented specific labeling in digestive and gonadal tissue. ISH testing on stages found positive by PCR also showed the presence of the parasite in ovarian tissues in CV and adult females (results not presented). $\mathrm{H}$ \& $\mathrm{E}$ staining of the CV stage showed two types of parasite cells invading the entire ovary (Fig. 4A): numerous tiny cells (1-3 $\mu \mathrm{m}$ ) inside and around oocytes (Fig. 4B) and larger Marteilia-like cells (15 $\mu \mathrm{m})$ (Fig. 4C). A section of non-infected ovarian tissue for a $\mathrm{CV}$ female is presented to highlight the normal form of oocytes (Fig. 4D).

\subsection{Detection of $M$. refringens in $P$. grani eggs}

Of the five EP experiments performed between September and November, three showed PCRpositive females ( $7^{\text {th }}$ October, $3^{\text {rd }}$ and $18^{\text {th }}$ November) (Table 1). A total of 18 pools of 30 eggs (corresponding to a total of 540 eggs) in October and 13 and 22 pools of 30 eggs (corresponding to a total of 1,050 eggs) in November were tested by PCR. No amplification was observed using PCR targeting ITS-1 rDNA whereas two pools of 30 eggs in October were found positive for $M$. refringens by nested PCR (Table 1). PCR products were sequenced in order to check that primers had adequately amplified the expected sequences. Three hundred and thirty-four nucleotides (nt) obtained sequences showed $99 \%$ of homology with M. refringens (GenBank accession numbers: EU854304, AM748040, AJ629366, AJ629361, AJ629360, AJ629358). 


\subsection{Frequency of detection of $M$. refringens in bivalves}

PCR, using universal primers, yielded amplification in $96 \%$ and $99 \%$ of samples of $M$. galloprovincialis and $R$. decussatus respectively (results not shown). Only these mussel and clam samples were subsequently tested by specific PCR for the detection of the parasite. Nested PCR products $(n=4)$ of $R$. decussatus were sequenced in order to check that primers had adequately amplified the expected sequences. The $288 \mathrm{nt}$ obtained sequences showed $100 \%$ of homology with $M$. refringens (GenBank accession numbers: AM504148, AM748037, AM504140, AJ629359). Marteilia refringens was detected all the year round in the digestive gland of My. galloprovincialis. The detection frequency of the parasite in this bivalve was bimodal. The first peak occurred in spring (April and May) with up to $50 \%$ detection and the second one in autumn (September and October) with up to 63\% detection using PCR (Fig. 5A). During winter and summer, detection frequencies were lower than $35 \%$. Maximum rates of infection in mussels were recorded when temperatures ranged from 15.0 to $21.0{ }^{\circ} \mathrm{C}$. For temperatures lower than $21^{\circ} \mathrm{C}$, a significant positive relationship was observed with detection frequency $(P<0.01)$ whereas over the whole range of temperatures no significant relationship $(P=0.82)$ was evident.

The frequency of detection of $M$. refringens in $R$. decussatus was higher in February (48.3\%), April (48.2\%) and September (68.9\%). The parasite was not detected in clams in July, August, November or December (Fig. 5B). Maximum detection frequency was observed at different temperatures and no significant relationship was observed between temperature and the detection frequency even for temperatures lower than $21^{\circ} \mathrm{C}(P>0.05)$.

\subsection{Description of M. refringens in bivalves}

In My. galloprovincialis, the intensity of infection was low from January to March and only young stages were observed, mainly in the stomach epithelium (Fig. 6A). From April, primary stages were more numerous, some appeared to be located in the digestive gland and the first mature stages, sporangia, were also observed in $15 \%$ of mussels observed in April and May $(n=33)$ (Fig. 6B). From June to August, few mussels were found positive by PCR and most of them showed young stages in the stomach epithelium (Fig. 6C). In September and October, the parasite appeared more abundant in mussels, including young stages in the stomach and digestive gland epithelia. Thirteen percent of mussels observed during these 2 months (31 mussels analyzed) displayed infection with mature sporangia. Few sporangia were observed in the intestinal lumen indicating a release of $M$. refringens into the water column (Fig. 6D). In November and December, most of the mussels showed young stages except for one in which mature sporangia were observed.

Fifty-eight $R$. decussatus found positive by nested PCR were tested by ISH. Unusual labeling of necrotic like cells was noticed in the digestive epithelium in four clams, two in June and two in September (Fig. 7).

\subsection{Retention efficiency experiments}

All copepod stages were retained by My. edulis. However, differences were observed between the tested groups. Maximum copepod retention efficiencies of My. edulis, 90 and $89 \%$, were observed for mussels in contact with eggs and nauplii respectively (Fig. 8). Copepodid stages appeared to be less well retained than eggs and nauplii with retention efficiencies between $20 \%$ and $40 \%$. A non-parametric Kruskal-Wallis ANOVA showed that differences between the 
different groups of stages filtered by $M y$. edulis were significant $(P<0.01)$. Post-hoc analyses revealed that these differences were significant on one hand between eggs /Cl-Cll and eggs/ $\mathrm{CVI}$, and on the other hand between nauplii /CI-CII and nauplii /CVI $(P<0.05)$.

\section{Discussion}

The present study investigated the presence and the dynamics of the protozoan $M$. refringens in different developmental stages of the copepod $P$. grani and two bivalve species, $M y$. galloprovincialis and $R$. decussatus, in Thau lagoon, the most important site for shellfish production on the French Mediterranean coast.

Marteilia-like cells have previously been observed by histology in $R$. decussatus but the species of parasite was not determined (Villalba, A., López, M.C., Carballal, M.J., 1993a, cited earlier). In the present case, $M$. refringens DNA was detected specifically by nested PCR in the digestive gland of $R$. decussatus continuously between January and June and then again in SeptemberOctober with detection frequencies ranging between 33 and $69 \%$. Because it was the first detection of $M$. refringens in $R$. decussatus by nested PCR, direct sequencing of some PCR products was performed in order to confirm the specific amplification of $M$. refringens DNA in tested samples. Moreover, individuals detected positive by PCR were selected for ISH testing to determine the location of the parasite in clams. Positive labeling was observed in $7 \%$ of tested clams suggesting that ISH is less sensitive than nested PCR. A comparative study previously conducted in mussels, revealed higher sensitivity of classic PCR (65\% of PCR-positive mussels) compared to smears/histology (20-25\% of infected mussels) (Pernas et al., 2001). Furthermore a second study performed comparing classic PCR and nested PCR showed that classic PCR is less sensitive than the latter (Carrasco et al., 2007a). However, this discrepancy can also suggest that parasite DNA is present in some clams but that the parasite is damaged or just present in the clams' digestive tracts. Our observations showed that $M$. refringens was not present in its usual form but rather as necrotic cells located in the stomach epithelium which could indicate that the parasite does not develop in clams. The detection of $M$. refringens in a burrowing organism could indicate that the parasite is present in the sediment, but may also be indicative of a high parasite abundance in the environment.

Data related to the frequency of detection of $M$. refringens in My. galloprovincialis and available in the literature are quite variable depending on sites studied but generally appear lower than detection frequencies obtained in the present study. Indeed, the maximum prevalence observed in Alfacs Bay (Spain) (26.7\%) (Carrasco et al., 2007b) or in Thermaikos Gulf (from 10 to 36\%) (Karagiannis and Angelidis, 2007) are much lower than in Thau (63\%). The seasonal pattern of the infection in mussels is also different between the sites studied. In Thau lagoon, the parasite and more specifically sporangial forms were mainly detected in April, May, September and October when temperatures ranged from 15.0 to $20.5^{\circ} \mathrm{C}$. In Alfacs Bay, higher prevalences were observed in July, August and September with temperatures higher than $17^{\circ} \mathrm{C}$ but the presence of mature sporangia was also reported during winter, meaning that sporulation occurred at low temperatures (Carrasco et al., 2007b). Similar results were described in Galicia where $M$. refringens sporulation occurred throughout the year with several peaks of prevalence (Villalba et al., 1993b). The sporulation of the parasite at low temperatures is not well understood but sudden changes in temperature have been pointed to as a trigger of parasite activation (Carrasco et al., 2008a). At our monitoring site, the detection frequency of $M$. refringens in mussels was bimodal with peaks in spring and autumn. Mature sporangia were only observed during these two seasons, suggesting that $M$. refringens may have two cycles per year with a 
potential period of transmission occurring from spring to autumn. The drastic decrease of prevalence observed between May and June could be due to the mortality of infected animals or to the elimination of the parasite by the mussel's defense mechanisms (Robledo and Figueras, 1995). Although no mortality was reported in mussels in Thau lagoon during the present study, $M$. refringens has previously been associated with significant mortality of My. galloprovincialis in Galicia or with negative effects on the reproduction of infected mussels (Villalba et al., 1993c; Camacho et al., 1997). More specifically, the highest prevalence and heavy infections coincided with post-spawing periods (Villalba et al., 1993c). In Thau lagoon, the breeding season of My. galloprovincialis occurs from March to June with a peak of spawning observed in April (Hamon, 1983, Croissance de la moule Mytilus galloprovincialis (Lmk) dans l'étang de Thau. Estimation des stocks de mollusques en France. PhD Thesis, University of Montpellier 2, France; Gagnery, 2003, Etude et modélisation de la dynamique des populations de bivalves en élevage (Crassostrea gigas et Mytilus galloprovincialis) dans le bassin de Thau (Méditerranée, France) et des ascidies solitaires associées. PhD Thesis, University of Montpellier 2, France) when a higher frequency of detection of $M$. refringens was observed. In June, environmental parameters (temperature $>17^{\circ} \mathrm{C}$ ) appeared optimum to allow the transmission and the development of the disease in mussels; nonetheless, detection frequency was low and no mature sporangia were observed. The presence of only young parasite stages in infected mussels suggests that these mussels were newly infected or had released mature stages. The increase of temperature during summer might have also contributed to reduce clearance rate as has been shown previously (Anestis et al., 2010) and consequently reduced the assimilation of the potential vector of the disease.

All $P$. grani copepodid stages were found positive to $M$. refringens by PCR (except CIV male) and it is the first time that the protozoan was detected by PCR in $P$. grani males. While $M$. refringens was not detected by $\mathrm{PCR}$ in $P$. grani nauplii, two egg samples from the EP experiments yielded amplification by nested PCR. PCR products obtained were then confirmed to be specific to $M$. refringens by sequencing. Although PCR assays are useful tools for pathogen detection, they only detect pathogen DNA. Consequently, a PCR-positive signal does not indicate that the tested organism is infected unless it is confirmed by histological observation (Burreson, 2008). However, testing zooplankton by ISH is quite challenging because of the size of the organisms (from $80 \mu \mathrm{m}$ for eggs to $1500 \mu \mathrm{m}$ for adults) and because of the lack of information regarding the prevalence of the parasite in the zooplanktonic community. Previous studies using ISH have demonstrated the presence of $M$. refringens in unidentified developmental copepodid stages of $P$. grani (probably CV) and adult females (Audemard et al., 2002; Carrasco et al., 2008b). Our results show for the first time the presence of the parasite in earlier stages, more particularly in the gonad, digestive epithelium and alimentary canal of CIII. The presence of $M$. refringens cells in the digestive tract of the copepod also suggested that the parasite is ingested by the copepod and migrates to the gonadal tissues as it has previously been hypothesized (Carrasco et al., 2008b). This hypothesis is strengthened by the presence of parasitic cells showing different size (from 3 to $10 \mu \mathrm{m}$ ) located in different tissues suggesting a multiplication of the parasite inside the copepod. The size of the parasite in copepod tissues was smaller than has previously been observed in bivalves but was similar to that observed by Carrasco et al. (2008b). Although the detection of parasite DNA in eggs was not confirmed by $\mathrm{ISH}$, results suggested that eggs could contribute (i) to spread the parasite especially because many eggs are produced by $P$. grani during the potential period of $M$. refringens transmission (up to 20.4 eggs $\mathrm{f}^{-1} \mathrm{~d}^{-1}$ in September) (Boyer et al., 2013) and (ii) to host the parasite during winter because $P$. grani produces eggs which undergo diapause from October to December in the lagoon (Boyer and Bonnet, 2013). During diapause, eggs settle in the sediment during winter and are suspected to allow overwintering of the parasite (Audemard et al., 2002). 
The comparison of the dynamics of infection of $M$. refringens in My. galloprovincialis and $P$. grani from April to November provides interesting information concerning the life cycle of the parasite in Thau lagoon. First of all, the peak of detection frequency in springtime associated with the description of the first mature parasite stages in My. galloprovincialis occurred concurrently with the increase in $P$. grani abundance in the water column. Therefore, the release of mature sporangia occurred just before the first PCR detection of the parasite in $P$. grani, supporting the hypothesis of a transmission of the parasite from bivalves to $P$. grani. This hypothesis has previously been confirmed by experimental transmission studies (Audemard et al., 2002; Carrasco et al., 2008b). The second peak of detection frequency in mussels was observed in September when $P$. grani was at peak abundance in the water column and when young developmental stages of $P$. grani were found positive using PCR and ISH. This detection frequency increase associated with the prevalence of more mature sporangia could be explained by both a development of the disease in mussels infected previously and an infection of naive mussels from infected copepods. Although the transmission of $M$. refringens from copepods to bivalves through ingestion has previously been hypothesized (Audemard et al., 2002; Carrasco et al., 2008b), there are no data available to support this suggestion and mussels are generally known to be herbivorous and to filter particles smaller than copepods, from 4 to $35 \mu \mathrm{m}$ (for My. edulis) (Strohmeier et al., 2012). Nevertheless, a study performed in the Magdalen Islands lagoon (Canada) has demonstrated that large-sized heterotrophic ciliates (size from 20 to 90 $\mu \mathrm{m})$ could also be assimilated by My. edulis (Trottet et al., 2008). In our study, all copepodites stages (from 350 to $1500 \mu \mathrm{m}$ size) were potentially retained by My. edulis with different efficiencies showing that all stages could be involved in the life cycle of $M$. refringens. Retention efficiency (85-90\%) was significantly higher for eggs (80 $\mu \mathrm{m}$ size) and nauplii (100-300 $\mu \mathrm{m}$ size) $(p<0.05)$ than for copepodid stages $(<40 \%)$. Copepod concentrations used in these experiments were about 10 times higher than in situ and a small volume $(1 \mathrm{~L})$ was used to maximize the probability of contact between copepods and mussels. We cannot be certain that the copepods retained by the mussels were assimilated by the mussel or released in the pseudofaeces (usuitable food expelled in musus without having passed through the digestive tract). Despite some limitations outlined above, results obtained from both field and experimental works provide new evidence for the contribution of $P$. grani to the life cycle of $M$. refringens.

\section{Acknowledgments}

The authors would like to thank Michel Cantou for the sampling of bivalves, Enric Saiz and Rosa Maria Borrat Padrosa for providing Paracartia grani eggs, Maximillien Cuny and Benoît Moirod for their help with PCR analyses, Maëva Robert for sequencing and Emmanuelle Omnes for histological slide preparation. The present study was supported by the GELAMED project through a grant allocated by the MEEDDM (Ministère de l'Ecologie, de l'Energie, du Développement Durable et de la Mer, France), and the Total foundation, France to D. Bonnet (Programme 189 - «Recherche » 18902 C). 
Alderman, D.J., 1979. Epizootiology of Marteilia refringens in Europe. Mar. Fish. Rev. 41, 67-69. Altschul, S.F., Gish, W., Miller, W., Myers, E.W., Lipman, D.J., 1990. Basic Local Alignement Search Tool. J. Mol. Biol. 215, 403-410.

Anestis, A., Portner, H.O., Karagiannis, D., Angelidis, P., Staikou, A., Michaelidis, B., 2010. Response of Mytilus galloprovincialis (L.) to increasing seawater temperature and to marteliosis: Metabolic and physiological parameters. Comp. Biochem. Phys. A 156, 57-66.

Audemard, C., Barnaud, A., Collins, C.M., Le Roux, F., Sauriau, P.G., Coustau, C., Blachier, P., Berthe, F.C.J., 2001. Claires ponds as an experimental model for Marteilia refringens lifecycle studies: new perspectives. J. Exp. Mar. Biol. Ecol. 257, 87-108.

Audemard, C., Le Roux, F., Barnaud, A., Collins, C.M., Sautour, B., Sauriau, P.G., (de) Montaudouin, X., Combes, C., Berthe, F.C.J., 2002. Needle in a haystack: involvement of the copepod Paracartia grani in the life-cycle of the oyster pathogen Marteilia refringens. Parasitology 124, 315-323.

Berthe, F.C.J., Pernas, M., Zerabib, M., Haffner, P., Thebault, A., Figueras, A.J., 1998. Experimental transmission of Marteilia refringens with special consideration of its life cycle. Dis. Aquat. Organ. 34, 135-144.

Boyer, S., Arzul, I., Bonnet, D., 2012. Some like it hot: Paracartia grani (Copepoda: Calanoida) arrival in the Thau lagoon (south of France-Mediterranean Sea). Marine Biodiversity Records 5, doi : 10.1017/S1755267212000565.

Boyer, S., Bonnet, D., 2013. Triggers for hatching of Paracartia grani (Copepoda: Calanoida) resting eggs: an experimental approach. J. Plank. Res.35, 668-676.

Boyer, S., Bouvy, M., Bonnet, D., 2013. What triggers Acartia species egg production in a Mediterranean lagoon? Estuar. Coast. Shelf S. 117, 125-135.

Burreson, E.M., 2008. Misuse of PCR assay for diagnosis of mollusc protistan infections. Dis. Aquat. Organ. 80, 81-83.

Camacho, A.P., Villalba, A., Beiras, R., Labarta, U., 1997. Absorption efficiency and condition of cultured mussels (Mytilus edulis galloprovincialis Linnaeus) of Galicia (NW Spain) infected by parasites Marteilia refringens Grizel et al. and Mytilicola intestinalis Steuer. J. Shellfish Res. 16, 77-82.

Carella, F., Aceto, S., Marrone, R., Maiolino, P., De Vico, G., 2010. Marteilia refringens infection in cultured and natural beds of mussels (Mytilus galloprovincialis) along the Campanian coast (Tirrenian sea, South of Italy). Bull. Eur. Assoc. Fish Pathol. 30, 189-196.

Carrasco, N., López-Flores, I., Alcaraz, M., Furones, M.D., Berthe, F.C.J., Arzul, I., 2007a. First record of a Marteilia parasite (Paramyxea) in zooplankton populations from a natural estuarine environment. Aquaculture 269, 63-70.

Carrasco, N., López-Flores, I., Alcaraz, M., Furones, M.D., Berthe, F.C.J., Arzul, I., 2007b. Dynamics of the parasite Marteilia refringens (Paramyxea) in Mytilus galloprovincialis and zooplankton populations in Alfacs Bay (Catalonia, Spain). Parasitology 134, 1541-1550.

Carrasco, N., Arzul, I., Berthe, F.C.J., Fernàndez-Tejedor, M., Dufort, M., Furones, M.D., 2008a. Delta de l'Ebre is a natural bay model for Marteilia spp. (Paramyxea) dynamics and lifecycle studies. Dis. Aquat. Organ. 79, 65-73.

Carrasco, N., Arzul, I., Chollet, B., Robert, M., Joly, J.P., Furones, M.D., Berthe, F.C.J., 2008b. Comparative experimental infection of the copepod Paracartia grani with Marteilia refringens and Marteilia maurini. J. Fish Dis. 31, 497-504.

Comps, M., 1970. Observations sur les causes d'une mortalité anormale des huîtres plates dans le bassin de Marennes. Rev. Trav. Inst. Pêch. Mar. 34, 317-326.

Comps, M., Joly, J.P. 1980. Contamination expérimentale de Mytilus galloprovincialis Lmk par Marteilia refringens. Sciences et Pêches: Bul. Inst. Pech. Mar. 301, $19-21$. 
Comps, M., Grizel, H., Tigé, G., Duthoit, J.L., 1975. Parasites nouveaux de la glande digestive des mollusques marins Mytilus edulis L. et Cardium edule. C. R. Acad. Sci. Paris 281, 179181.

Elgharsalli, R., Aloui-Bejaoui, N., Salah, H., Chollet, B., Joly, J.-P., Robert, M., Couraleau, Y., Arzul, I., 2013. Characterization of the protozoan parasite Marteilia refringens infecting the dwarf oyster Ostrea stentina in Tunisia. J. Invertebr. Pathol. 112,175-183.

Karagiannis, D., Angelidis, P., 2007. Infection of cultured mussels Mytilus galloprovincialis by the protozoan Marteilia sp. in the Thermaikos Gulf (N Greece). Bull. Eur. Assoc. Fish Pathol. 27, 131-141.

Lam Hoai, T., 1985. Evolution saisonnière du zooplancton dans trois sites peu profonds de Thau, une lagune Nord-Méditerranéenne. Hydrobiologia 128, 161-174.

Le Roux, F., Audemard, C., Barnaud, A., Berthe, F., 1999. DNA probes as potential tools for the detection of Marteilia refringens. Mar. Biotechnol. 1, 588-597.

Le Roux, F., Lorenzo, G., Peyret, P., Audemard, C., Figueras, A., Vivares, C., Gouy, M., Berthe, F.C.J., 2001. Molecular evidence for the existence of two species of Marteilia in Europe. J. Eukaryot. Microbiol. 48, 449-454.

Lindeque, P.K., Boyer, S., Bonnet, D., 2013. A molecular method for the identification of resting eggs of acartiid copepods in the Thau lagoon, France. Mar. Biol. 160, 737-742.

López-Flores, I., de la Herran, R., Garrido-Ramos, M.A., Navas, J.I., Ruiz-Rejon, C., Ruiz-Rejon, M., 2004. The molecular diagnosis of Marteilia refringens and differentiation between Marteilia strains infecting oysters and mussels based on the rDNA IGS sequence. Parasitology 129, 411-419.

López-Flores, I., Garrido-Ramos, M., de la Herran, R., Ruiz-Rejon, C., Ruiz-Rejon, M., Navas, J.I., 2008a. Identification of Marteilia refringens infecting the razor clam Solen marginatus by PCR and in situ hybridization. Mol. Cell. Probe. 22, 151-155.

López-Flores, I., Robles, F., Valencia, J.M., Grau, A., Villalba, A., de la Herran, R., GarridoRamos, M.A., Ruiz-Rejon, C., Ruiz-Rejon, M., Navas, J.I., 2008b. Detection of Marteilia refringens using nested PCR and in situ hybridization in Chamelea gallina from the Balearic Island (Spain). Dis. Aquat. Organ. 82, 79-87.

Mathias, P., Euzet, L., 1962. Le plancton du bassin de Thau (Etang des Eaux Blanches). Naturalia Monspeliensia 4, 7-28.

Novoa, B., Posada, D., Figueras, A., 2005. Polymorphisms in the sequence of Marteilia internal transcriber spacer region of the ribosomal RNA genes (ITS-1) in Spain: genetic types are not related with bivalve hosts. J. Fish. Dis. 28, 331-338.

Pëllumb, A., Ceschia, G., Kapllan, S.; 2006. First report of Marteiliosis in Mytilus galloprovincialis in Albania. Ittiopatologia 3, 47-52.

Pernas, M., Novoa, B., Berthe, FC.J., Tafalla, C., Figueras, A., 2001. Molecular methods for the diagnosis of Marteilia refringens. Bull. Eur. Assoc. Fish Pathol. 21, 200-209.

Robledo, J.A.F., Figueras, A., 1995. The Effects of culture-site, depth, season, and stock source on the prevalence of Marteilia refringens in cultured mussels (Mytilus-galloprovincialis Lmk) from Galicia, Spain. J. Parasitol. 81, 354-363.

Strohmeier, T., Strand, O., Alunno-Bruscia, M., Duinker, A., Cranford, P.J., 2012. Variability in particle retention efficiency by the mussel Mytilus edulis. J. Exp. Mar. Biol. Ecol. 412, 96102.

Tieri, E., Ceschia, G., Cannone, N., Giansante, C., 2006. Presence of Marteilia refringens in European flat oysters (Ostrea edulis) natural bank in the Adriatic Sea, Italy. Ittiopatologia 3, 41-45.

Trottet, A., Roy, S., Tamigneaux, E., Lovejoy, C., Tremblay, R., 2008. Impact of suspended mussels (Mytilus edulis L.) on plankton communities in a Magdalen Islands lagoon (Quebec, Canada): A mesocosm approach. J. Exp. Mar. Biol. Ecol. 365, 103-115. 
Villalba, A., Mourelle, S.G., López, M.C., Carballal, M.J., Azevedo, C., 1993b. Marteiliosis affecting cultured mussels Mytillus galloprovincialis of Galicia (NW Spain). I. Etiology, phases of the infection, and temporal and spatial variability in prevalence. Dis. Aquat. Organ. 16, 61-72.

Villalba, A., Mourelle, S.G., Carballal, M.J., López, M.C., 1993c. Effects of infection by the protistan parasite Marteilia refringens on the reproduction of cultured mussels Mytilus galloprovincialis in Galicia (Nw Spain). Dis. Aquat. Organ. 17, 205-213.

Virvilis, C., Angelidis, P., Photis, G., 2003. Presence of the parasite Marteilia sp. in the shellfish of the Thermaikos Gulf in Northern Greece. Bull. Eur. Assoc. Fish Pathol. 23, 157-162.

Zrnčić , S., Le Roux, F., Oraić , D., Šoštaric, B. and Berthe, F. C. J., 2001. First record of Marteilia sp in mussels Mytilus galloprovincialis in Croatia. Dis. Aquat. Organ. 44, 143-148.

\section{Figure legends}

Fig. 1. Map of Thau lagoon, France. The triangle represents the mesozooplankton monitoring site and the localization of bivalve sampling.

Fig. 2. Detection of Marteilia refringens in copepodite stages of Paracartia grani in the Thau lagoon, France, during occurrence of the copepod in the water column in 2010 (A) Contribution of $P$. grani to total zooplankton abundance and PCR detection of $M$. refringens. + , at least one sample was positive by PCR. Brackets indicate that samples were pooled. (B) PCR-positive detections and in situ hybridization labeling in each developmental stage of P. grani. +, PCRpositive detection targetting ITS-1; N, PCR-positive detection by nested PCR (targeting IGS). *, stages $\mathrm{Cl}$ and $\mathrm{Cll}$ represent a mix of $P$. grani and Acartia clausi (see Section Materials and Methods for explanation). $\mathrm{H}$, localisation of the parasite by ISH.

Fig. 3. Marteilia refringens cells stained by in situ hybridization in copepodid stage III (CIII) of Paracartia grani. (A) Alimentary canal epithelium, (B) digestive epithelium, (C) germinal site of ovary.

Fig. 4. Histological examination of Marteilia refringens infection in a copepodid stage $V(C V)$ female Paracartia grani (H \& E stained sections). (A) The entire ovary appears to be infected with two types of cells (B and $C)$. (B) Numerous tiny cells $(1-3 \mu \mathrm{m})$ were observed inside and around oocytes. (C) Marteilia-like cells $(15 \mu \mathrm{m})$. (D) Non-infected ovary of $P$. grani CV showing different oocyte stages.

Fig. 5. PCR detection frequency of Marteilia refringens in the digestive gland of two bivalves in Thau lagoon, France: (A) Mytilus galloprovincialis, (B) Ruditapes decussatus. Squares represent the in situ temperatures recorded in 2010 and bars indicate S.D.s. S, records of sporangia in mussel samples; ISH, positive in situ hybridization assays in clams.

Fig. 6. Different Marteilia refringens stages (arrows) observed in Mytilus galloprovincialis in different seasons by light microscopy (H \& E stained histological sections). (A) Winter: young 
stages in stomach epithelium; (B) Spring: mature sporangia in the epithelium of digestive diverticula; (C) Summer: young stages in stomach epithelium; (D) Autumn: mature sporangia in the epithelium and the lumen of stomach.

Fig. 7. Detection of Marteilia refringens (arrows) in the stomach epithelium of Ruditapes decussatus by $(A)$ in situ hybridization and $(B) H$ \& $E$ staining.

Fig. 8. Retention efficiency by Mytilus edulis of the different stages of Paracartia grani. Bars: S.D. Number of replicates $(n)$ used in each experiment is indicated above each histogram. The seven $P$. grani assemblages (eggs, NIII-NIV, NV-NVI, CI-CII, CIII-CIV, CV, CVI) and their size ranges are indicated. 


\begin{tabular}{cccccc}
\hline & 21-Sep & 7-Oct & 3-Nov & 18-Nov & 29-Nov \\
\hline \multirow{2}{*}{ Females CVI } & - & + & + & + & - \\
& & & & & \\
\multirow{2}{*}{ Eggs } & & + & - & - & \\
& & $(2 / 18)$ & $(0 / 13)$ & $(0 / 22)$ & \\
\hline
\end{tabular}

Table 1: Results of nested PCR in eggs samples from egg production experiments. Brackets indicate the number of positive PCR on the total tested replicates. 


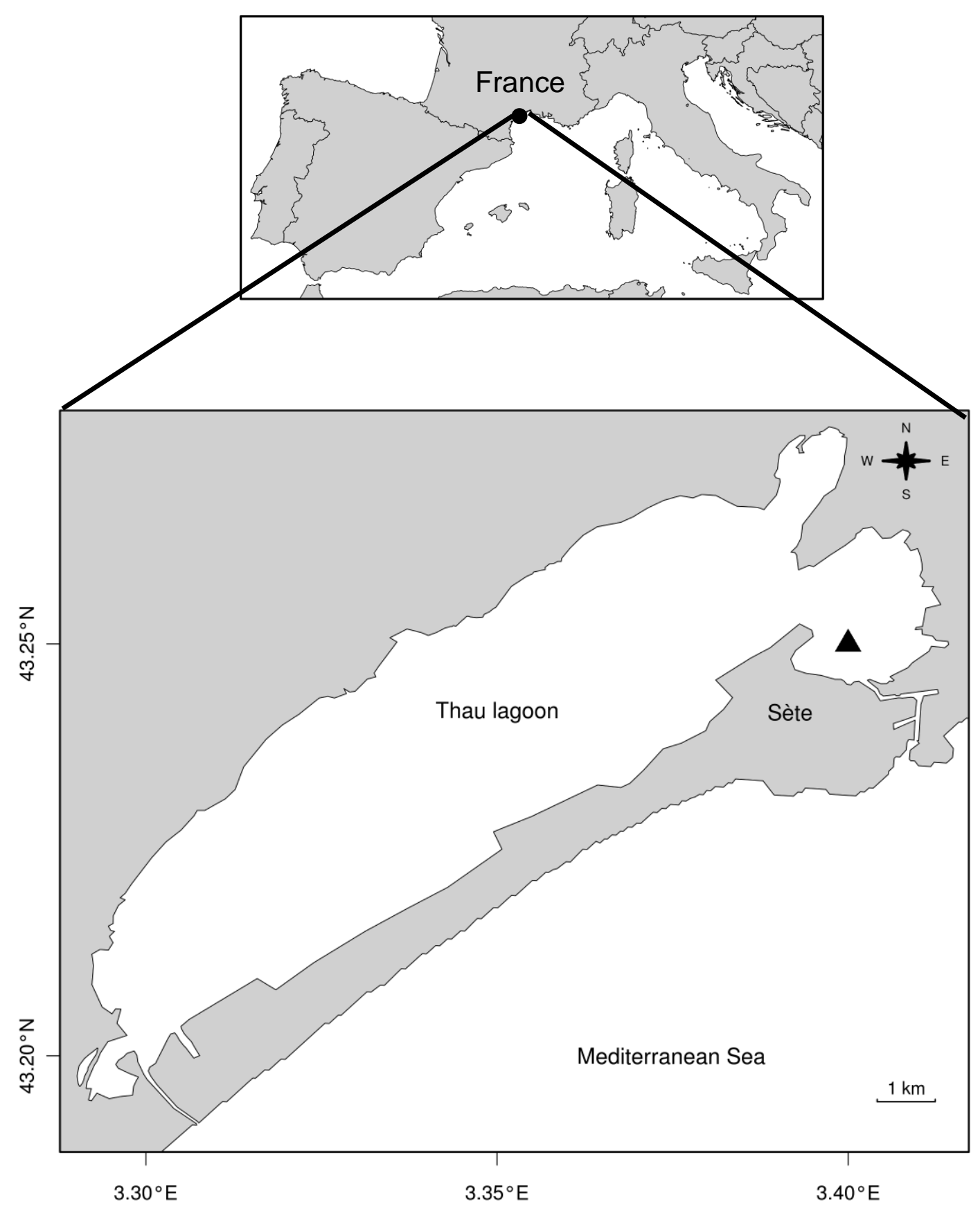

Figure 1 


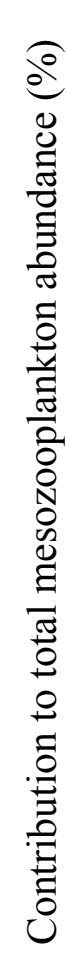

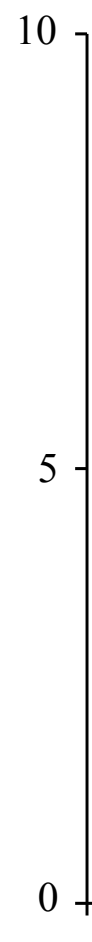

Not recorded

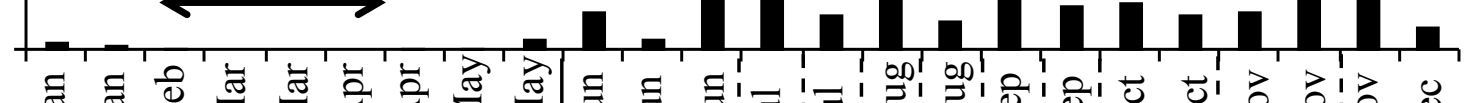

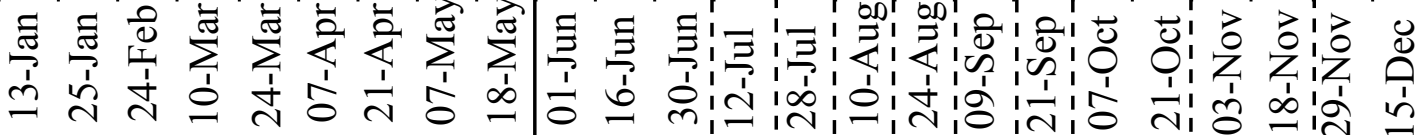

B

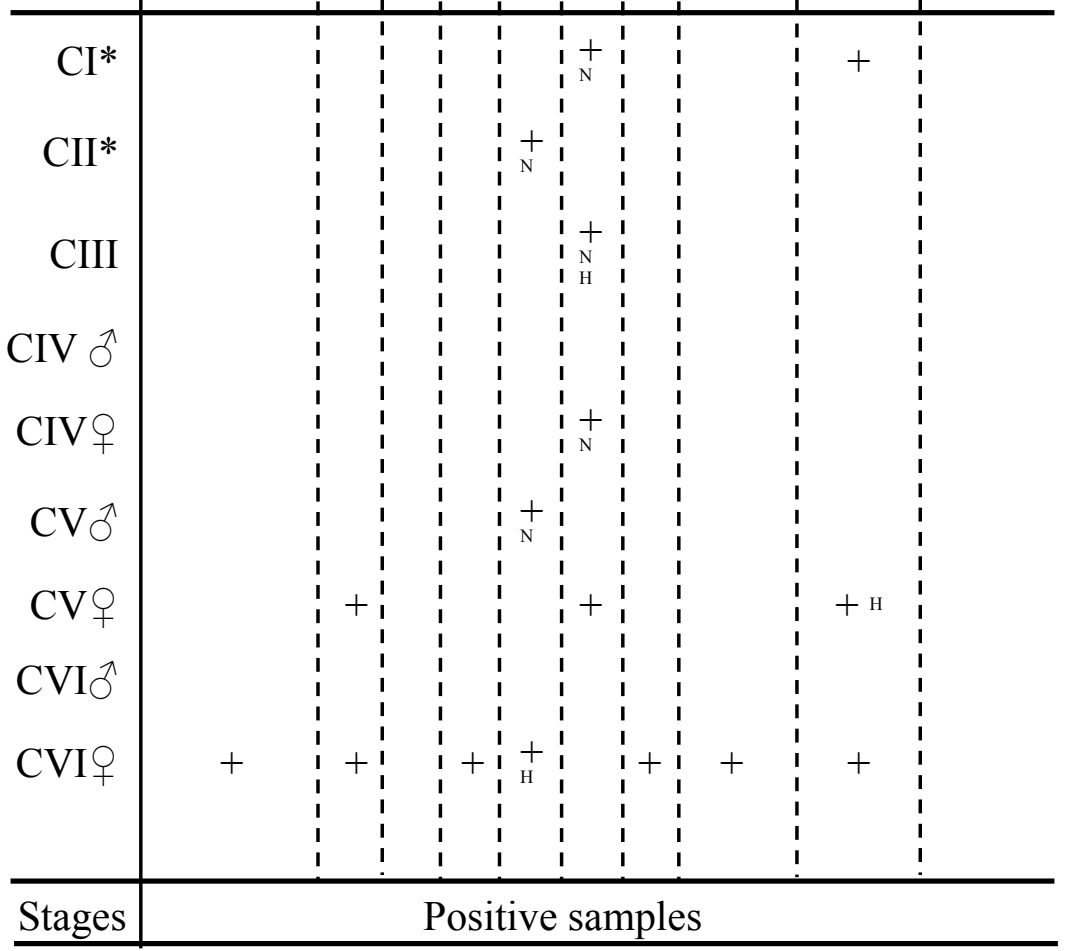

Figure 2 


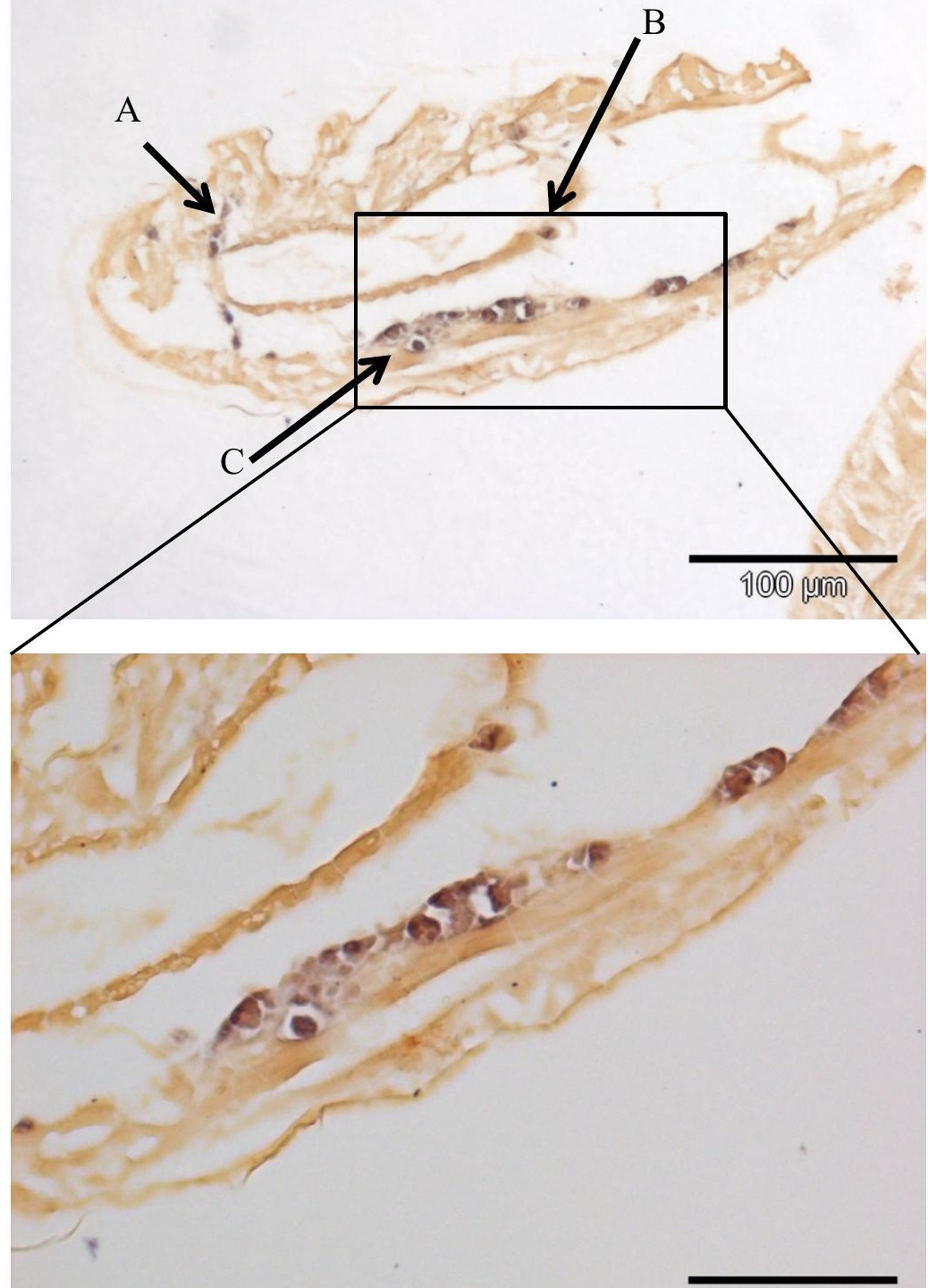

50 ตัก

Figure 3 


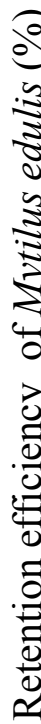

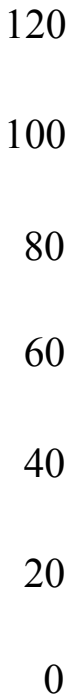

$n=4 \quad n=4 \quad n=4$

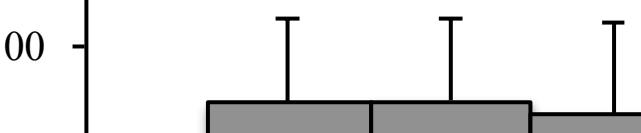

P. grani assemblages

Length $(\mu \mathrm{m}) \quad 70-80$

$100-300$

350- 450

500- 700

$700-850$

CVI

Figure 8 